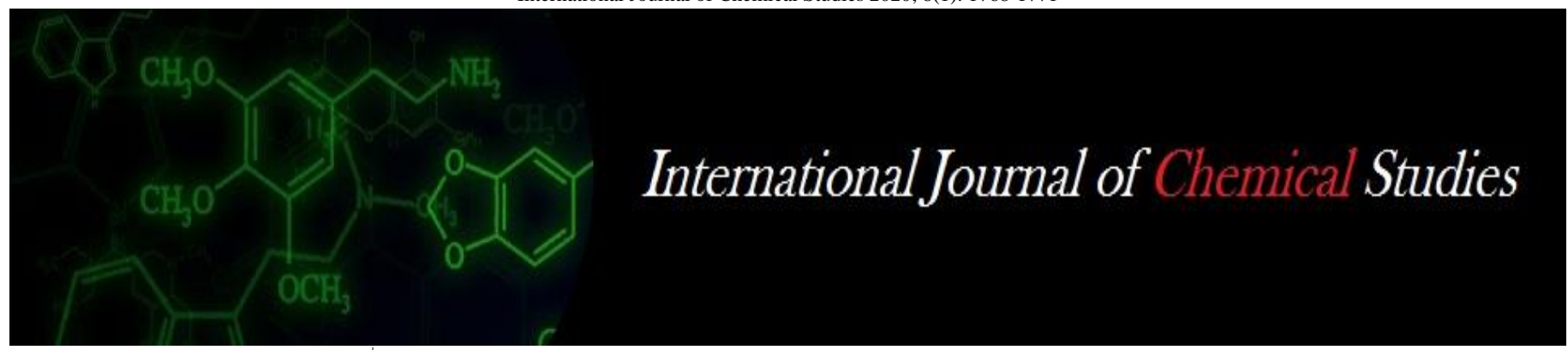

P-ISSN: 2349-8528

E-ISSN: 2321-4902

IJCS 2020; 8(1): 1768-1771

(C) 2020 IJCS

Received: 06-11-2019

Accepted: 10-12-2019

Rajanna B

Ph.D. Scholar, Department of Genetics and Plant breeding,

UAHS, Shivamogga, Karnataka, India

\section{Gangaprasad S}

Professor, Department of Genetics and Plant breeding,

UAHS, Shivamogga, Karnataka, India

\section{Shanker Goud I}

The Dean (PG studies), UAS,

Raichur, Karnataka, India

\section{Dushyantha Kumar BM}

Professor, Department of

Genetics and Plant breeding,

UAHS, Shivamogga, Karnataka,

India

\section{Girijesh GK}

Professor, Department of

Agronomy, UAHS, Shivamogga

Karnataka, India

\section{Sathish KM}

Assistant Professor, Department of Biotechnology, UAHS, Shivamogga, Karnataka, India

Corresponding Author:

Rajanna B

Ph.D. Scholar, Department of Genetics and Plant breeding,

UAHS, Shivamogga, Karnataka, India

\section{Genetic variability, heritability and genetic advance of yield components and oil quality parameters in linseed (Linum usitatissimum L.)}

\author{
Rajanna B, Gangaprasad S, Shanker Goud I, Dushyantha Kumar BM, \\ Girijesh GK and Sathish KM
}

DOI: https://doi.org/10.22271/chemi.2020.v8.i1z.8520

\begin{abstract}
One hundred linseed (Linum usitatissimum L.) genotypes and four checks were evaluated during rabi, 2017-18 for fifteen traits to examine the nature and magnitude of variability, heritability (h2=broad sense) and genetic advance. Analysis of variance revealed that the differences among genotypes were significant for all the characters studied. Knowledge of selection effect on positive or negative changes of a character under improvement is of paramount importance for the success of any plant breeding programme and helps the selection of desirable breeding methods. Heritability and genetic advance are important selection parameters and selection success is a reflectance of selection response. High PCV and GCV values exhibited for number of branches per plant, number of capsules per plant, yield per plant, palmitic acid and linoleic acid indicating wide range of variability with substantial environmental influence on the expression of these traits and provide better opportunity for improvement of these traits through selection. Small differences between GCV and PCV were recorded for all the characters studied which indicated less influence of environment on these characters. High heritability coupled with high Genetic advance as per cent of Mean (GAM > 20\%) observed for plant height, technical plant height, number of branches per plant, number of capsules per plant, yield per plant, palmitic acid, stearic acid, oleic acid, linoleic acid and linolenic acid indicated that these characters are highly heritable.
\end{abstract}

Keywords: Genetic variability, genetic advance, Linum usitatissimum

\section{Introduction}

Linseed [(Linum usitatissimum L. $),(2 \mathrm{n}=2 \mathrm{X}=30)$ ] is a self-pollinated crop and commonly known as Alsi in Hindi, Agase in Kannada. It is an important oilseed and fibre crop of the tropical as well as temperate regions of the world. Linseed is one of the most important industrial oilseed crops of India and its cultivation goes back to more than 5000 years. The genus Linum belongs to family Linaceae and orders Geraniale and is the only species in the family which is of economic importance. In western temperate countries, linseed is more commonly known as "Flax", where it is exclusively cultivated for the fiber called linen. Based on the diversity of plant types, linseed has two centres of origin i.e., Central Asia and the Mediterranean area of Europe (Darlington, 1963) ${ }^{[5]}$.

Linseed is rich in fat, protein and dietary fiber, it contains about 41 per cent fat, 28 per cent dietary fiber, 21 per cent protein, three per cent carbohydrate and also an important source of magnesium, potassium, zinc and B vitamins, soluble fibers $(25 \%)$ and insoluble fiber $(75 \%)$. Every part of the linseed plant is utilized commercially either directly or after processing. The linseed oil is also used in industries for the manufacture of paints, varnish, oilcloth, linoleum and pad ink (Walsh, 1965) ${ }^{[20]}$. The oil cake is a good feed for milch cattle and also used as organic manure to maintain soil fertility as well as to prevent the unwanted microbes with its germicidal properties. The stem yields fiber of good quality having high strength and durability.

Linseed encompasses the potential health suiting nutritional profile in it. The oil possesses a very healthy fatty acid profile and it contains the richest source of omega- 3 fatty acid or ALA (Alpha-Linolenic Acid) 58 per cent and it is essential fatty acid as it cannot be synthesized in the human body and must be supplemented directly from foods. Omega- 3 fatty acid provides beneficial effects in numerous clinical conditions such as cardiovascular disease, blood 
pressure, heart beat rate, blood clotting and inflammatory disorders. Further it also improves digestibility, bioactive peptides, antimicrobial, anti-Parkinson's, anti-proliferative, antihypertensive, immune-enhancing, antiulcer and antioxidant activities. Both fish source of omega-3 fatty acids are EPA (Eicosa Pentaenoic Acid), DHA (Docosa Hexaenoic Acid) and plant based omega-3 fatty acid (Alpha Linolenic Acid) which are rich in linseed crop.

Variability in a crop species is of utmost importance as it provides the basis for effective selection. Variability in a population is measured by phenotypic and genotypic coefficients of variation. The information on the nature and magnitude of genetic variability present in a population is a prerequisite to start any crop improvement programme. Yield being a complex character is dependent on many quantitatively inherited component characters and wider range of genetic variability helps in selecting desired genotypes. In addition to the genetic variability, knowledge on heritability and expected genetic advance helps the breeder to employ the suitable breeding strategy. Therefore, it is necessary to have knowledge of genetic variability, heritability and genetic advance in the available genetic material.

\section{Material and Methods}

The experimental material for this study consisted of hundred germplasm lines along with four checks (NL-115, PCL-57, T397 and Padmini) which were obtained from AICRP on Linseed, MARS, Raichur and Project co-ordinating unit (Linseed), Kanpur. These lines were selected based on their wider adaptability to different agro-climatic regions as well as diverse growing conditions. These includes of released varieties, local land races, mutants and advanced breeding lines.

One hundred linseed germplasm and four checks were planted in augmented design (Federer, 1956) ${ }^{[6]}$. The entire experimental plot was divided into five blocks, checks were repeated in each block and each line has a single row of three meter length with the spacing of $30 \times 5 \mathrm{~cm}$. All the material along with four checks was sown on 31.10.2016 in the experimental blocks of Main Agricultural Research Station, University of Agricultural Sciences, Raichur, Karnataka. All the recommended crop production and protection practices were followed to raise a healthy crop.

Observations on five randomly selected plants in each genotype and checks were recorded for morphological and yield characters. The average values were computed as genotype mean and check means in each block. Oil content was estimated with the help of Nuclear Magnetic Resonance (NMR) at Main Agricultural Research Station, Raichur and expressed as per cent. This instrument gave a direct value of oil percentage in seeds that were previously oven dried.

Fatty acids content was estimated with the help of Gas Chromatographer at Project Coordinating Unit (Linseed), Kanpur.

The mean data after computing for each character was subjected to standard method of analysis of variance following Panse and Sukhatme (1961), genotypic coefficient of variation (GCV) and phenotypic coefficient of variation (PCV), heritability in broad sense $\left(\mathrm{h}_{\mathrm{b}}{ }^{2}\right)$ and genetic advance as per cent of mean were estimated by the formula as suggested by Burton (1953) ${ }^{[4]}$ and Johanson et al., (1955) ${ }^{[9]}$.

\section{Results and Discussion}

The genetic variability parameters viz., mean, range, phenotypic coefficient of variation (PCV), genotypic coefficient of variation (GCV), heritability (broad sense) and genetic advance as per cent mean (GAM) for all the fifteen characters are presented in the (Table 1). All the fifteen traits under study showed wide range of variation indicating an enormous opportunity for bringing about improvement in essential direction.

The analysis of variance revealed significant differences among the genotypes for all characters, indicating a high degree of variability in the material studied. This had been exemplified by highly significant mean sum of squares for these traits, which indicated that, the genotypes under study were genetically diverse.

Phenotypic coefficient of variation (PCV) ranged between 5.51 per cent (Days to maturity) to 41.08 per cent (Linoleic acid). Genotypic co-efficient of variation (GCV) ranged between 5.49 per cent (Days to maturity) to 41.07 per cent (Linoleic acid). Broad-sense heritability ranged from 80.48 per cent (Yield per plant) to 99.97 per cent (Linolenic acid). Genetic advance as per cent of mean ranged between 11.26 per cent (Days to maturity) to 84.58 per cent (Linoleic acid). Moderate PCV and GCV observed for traits like plant height (16.33 and 16.25), technical plant height (19.50 and 19.39), stearic acid (16.18 and 15.98), oleic acid (12.28 and 12.26) and linolenic acid (11.30 and 11.28) indicating that these traits should be given due importance while selecting high yielding genotypes. These results are in accordance with reports of other workers in linseed by Shipra et al. (2016) ${ }^{[15]}$, Frank et al. (2017) ${ }^{[7]}$ and Amith et al. (2017) ${ }^{[1]}$.

High PCV and GCV values exhibited for number of branches per plant, number of capsules per plant, yield per plant, palmitic acid and linoleic acid indicating wide range of variability with substantial environmental influence on the expression of these traits and provide better opportunity for improvement of these traits through selection. Similar results of high PCV and GCV values for above said traits were also reported by Bibi et al. (2013) [3], Ranjana et al. (2018) ${ }^{[14]}$, Vipin et al. (2019) ${ }^{[18]}$ and Ankit et al. (2019) ${ }^{[2]}$. Coefficients of variation studies indicated that the estimates of PCV were slightly higher than the corresponding GCV estimates for all the traits studied indicating that the characters were less influenced by the environment. Therefore, selection on the basis of phenotype alone can be effective for the improvement of these traits.

Genetic variability, heritability and genetic advance are of great importance in improving the yield of a genotype (Gupta and Verma et al., 2000) ${ }^{[8]}$. With the help of GCV alone it may not be feasible to determine the amount of heritable variation and the relative degree to which a character is transmitted from parent to offspring is indicated by the estimate of heritability. Heritability estimates along with genetic advance are normally helpful in predicting the gain under selection than heritability estimate alone. Hence, both heritability and genetic advance were determined to get a clear picture of the scope of improvement in various characters through selection. Heritability is classified as low (below 30\%), medium (30$60 \%$ ) and high (above 60\%). The characters studied in the present investigation expressed high heritability estimates ranging from 80.48 to 99.97 per cent. The genetic advance is a useful indicator of the progress that can be expected as result of exercising selection on the pertinent population. Heritability in conjunction with genetic advance would give a more reliable index of selection value (Johnson et al., 1955) ${ }^{[9]}$.

High heritability coupled with high Genetic Advance as per cent of Mean (GAM >20\%) observed for plant height, technical plant height, number of branches per plant, number 
of capsules per plant, yield per plant, palmitic acid, stearic acid, oleic acid, linoleic acid and linolenic acid indicated that these characters are highly heritable. Panse and Shukhatme (1978) ${ }^{[12]}$ have expressed that if a character is governed by additive gene action, directional phenotypic selection of these traits could be more effective for desired genetic improvement, heritability and genetic advance both would be high. The findings of higher heritability and expected genetic advance are in line with the findings of Vishnuvardhan and Rao (2012) ${ }^{[19]}$, Kumar et al. (2012) ${ }^{[10]}$, Pali and Mehta (2013) ${ }^{[11]}$, Amith et al. (2017) ${ }^{[1]}$, Frank et al. (2017) ${ }^{[7]}$ and Ranjana et al. (2018) ${ }^{[14]}$. High heritability is suggestive of the scope for higher genetic gain in seed yield through selection (Todorovic et al., 2011) ${ }^{[16]}$.
High heritability coupled with moderate genetic advance as per cent of mean was observed indicating the role of both additive and non-additive gene action governing the inheritance of days to 50 per cent flowering, days to maturity, number of seeds per capsule and 1000 seed weight. These results are in broad agreement with the reports of Vikas and Nandan (2014) ${ }^{[17]}$.

Paul (1978) ${ }^{[13]}$ also reported that, if heritability in broad sense is mainly due to additive gene effects then only it associates with high genetic gain. If the heritability in broad sense is mainly due to non-additive effects (dominance and / or epistasis), the genetic gain will be low as observed in the case of days to 50 per cent flowering, days to maturity, number of seeds per capsule and 1000 seed weight.

Table 1: Genetic variability parameters for yield and oil quality parameters in linseed (Linum usitatissimum L.)

\begin{tabular}{|c|c|c|c|c|c|c|c|c|c|}
\hline \multirow{2}{*}{ Sl. No. } & \multirow{2}{*}{ Characters } & \multirow{2}{*}{ Mean } & \multicolumn{2}{|c|}{ Range } & \multicolumn{2}{|c|}{ Coefficient of variation (\%) } & \multirow{2}{*}{\begin{tabular}{|l}
$\mathbf{h}^{2}$ bs \\
$(\%)$
\end{tabular}} & \multirow{2}{*}{ GA $(\%)$} & \multirow{2}{*}{$\begin{array}{c}\text { GAM } \\
(\%)\end{array}$} \\
\hline & & & Minimum & Maximum & PCV & GCV & & & \\
\hline 1 & Days to $50 \%$ flowering & 55.08 & 32.00 & 62.00 & 7.03 & 6.96 & 98.17 & 7.83 & 14.21 \\
\hline 2 & Days to maturity & 108.17 & 89.00 & 125.00 & 5.51 & 5.49 & 99.15 & 12.18 & 11.26 \\
\hline 3 & Plant height $(\mathrm{cm})$ & 50.18 & 30.00 & 71.00 & 16.33 & 16.25 & 98.91 & 16.53 & 33.29 \\
\hline 4 & Technical plant height $(\mathrm{cm})$ & 35.52 & 20.00 & 60.00 & 19.50 & 19.39 & 98.88 & 13.55 & 39.72 \\
\hline 5 & Number of branches per plant & 4.92 & 3.00 & 8.00 & 35.47 & 33.90 & 91.44 & 3.27 & 66.79 \\
\hline 6 & Number of capsules per plant & 53.43 & 33.00 & 86.00 & 25.55 & 25.23 & 97.53 & 28.30 & 51.34 \\
\hline 7 & Number of seeds per capsule & 6.75 & 5.00 & 8.00 & 9.58 & 8.99 & 88.03 & 1.17 & 17.39 \\
\hline 8 & 1000 seed weight $(\mathrm{g})$ & 6.07 & 4.58 & 7.25 & 8.66 & 8.42 & 94.38 & 1.00 & 16.85 \\
\hline 9 & Yield per plant (g) & 2.19 & 1.11 & 3.87 & 30.09 & 27.00 & 80.48 & 1.10 & 49.89 \\
\hline 10 & Oil content $(\%)$ & 32.69 & 26.93 & 38.35 & 6.81 & 6.79 & 99.52 & 4.48 & 13.96 \\
\hline 11 & Palmitic acid (\%) & 7.30 & 5.68 & 11.05 & 34.80 & 34.78 & 99.90 & 5.46 & 71.67 \\
\hline 12 & Stearic acid $(\%)$ & 5.81 & 3.356 & 7.56 & 16.18 & 15.98 & 97.62 & 1.85 & 32.54 \\
\hline 13 & Oleic acid (\%) & 31.95 & 17.21 & 41.72 & 12.28 & 12.26 & 99.72 & 7.96 & 25.23 \\
\hline 14 & Linoleic acid (\%) & 12.93 & 8.06 & 53.34 & 41.08 & 41.07 & 99.90 & 10.97 & 84.58 \\
\hline 15 & Linolenic acid (\%) & 41.30 & 12.64 & 50.12 & 11.30 & 11.28 & 99.97 & 9.60 & 23.22 \\
\hline
\end{tabular}

Where,

$\mathrm{PCV}=$ Phenotypic coefficient of variation

$\mathrm{GCV}=\mathrm{Genotypic}$ coefficient of variation $\mathrm{h}^{2} \mathbf{b s}=$ Heritability in broad $\quad \mathrm{GA}=$ Genetic advance

$\mathrm{GAM}=$ Genetic advance as per cent mean

\section{Summary and conclusion}

Analysis of variance revealed the presence of adequate variability among the germplasm lines for all the fifteen characters. A close correspondence between PCV and GCV was noticed for most of the characters indicated the fact that the environmental influence is very low and hence selection for characters would be made based on their phenotypic performance. High heritability coupled with high GAM observed for plant height, technical plant height, number of branches per plant, number of capsules per plant, yield per plant, palmitic acid, stearic acid, oleic acid, linoleic acid and linolenic acid suggested that these characters are highly heritable and these traits could be improved by simple selection procedures.

\section{Acknowledgement}

The author is grateful to Linseed Breeder, AICRP on Linseed, MARS, University of Agricultural Sciences, Raichur and Project coordinator, Project Coordinating Unit, Kanpur for providing seed material, their help and valuable suggestions during the work.

\section{References}

1. Amit Kumar SA, Kerkhi, Rohit Kumar. Genetic diversity (D2) analysis in Linseed (Linum usitatissimum L.), J Pharmacognosy and Phytochemistry. 2017; 6(4):886-888.

2. Ankit SA, Kerkhi, Shivendrapratap Singh, Vipin Kumar Singh, Anjali Singh, Ankaj Tiwari., Estimates of indirect selection parameters through correlation and path analysis in linseed (Linum usitatissimum L.), Intl. J. Chemical Studies. 2019; 7 (1):2461-2465.

3. Bibi T, Mahmood T, Mirza Y, Mahmood T, Hasan EU. Correlation studies of some yield related trait in linseed (Linum usitatissimum L.), J Agr. Res. 2013; 51(2):121131.

4. Burton GW, De Vane EM. Estimating heritability in tall Fescue (Festuca arundinaceae L.) from replicated clonalmaterial, Agron. J. 1953; 51:515-518.

5. Darlington CD. Botany and the origin of cultivated plants, George Allen and Unwin Ltd., London, 1963.

6. Federer W. Augmented designs, Hawaiian Planters Record. 1956; 55:191-208.

7. Frank M, Jia G, Xiao J, Duguid SD, Rashid KY, Booker HM et al. Genetic variability of 27 traits, in a core collection of flax (Linum usitatissimum L.), Front. Plant Sci. 2017; 8:1636.

8. Gupta SK, Verma SR. Variability, heritability and genetic advanceunder normal and rainfed condition in duram wheat (Triticum aestivum L.), New Botanist. 2000; 39:49-54.

9. Johnson HW, Robinson HI, Comstock RE. Estimation of genetic and environmental variability in soybean, Agron. J. 1955; 47:314-318.

10. Kumar S, Kerkhi AS, Gangwar KL, Chana P, Kumar M. Improvement in the genetic architecture through study of variability, heritability and genetic advance in linseed crop (Linum usitatissimum L.), Intl. J Res. in Engi. IT and Soc. Sci. 2012; 6:58-65. 
11. Pali V, Mehta N. Studies on genetic variability correlation and path analysis for yield and its attributes in linseed (Linum usitatissimum L.), Plant Archives. 2013; 13(1):223-227.

12. Panse VG, Sukhatme PV, Statistical Methods for Agricultural Workers, I. C. A. R., New Delhi (India), 1978.

13. Paul NK. Genetic architecture of yield and components of yield in mustard (Brassica juncea L.), Theoretical and Appl.Genet. 1978; 53:233-237.

14. Ranjana Patiala, Satish Paul, Devender Sharma. Correlation and path coefficient analysis for improvement of seed yield in Linseed (Linum usitatissimum L.), Intl. J Current Microbiol. Appl. Sci. 2018; 7(3):1853-1860.

15. Shipra Shalini, Sohan Ram, Shanti Bhushan, Ekhlaque Ahmad. Genetic variability, heritability and genetic advance of yield and quality traits in linseed (Linum usitatissimum L.), Intl. J Plant Sci. 2016; 11(2):270-274.

16. Todorovic G, Zivanovic T, Jevdjovic R, Kostic M, Djordjevic R, Zecevic B et al. The mode of inheritance of grain yield in two single- cross maize (Zea mays L.) hybrids, Romanian Agr. Res. 2011; 28:71-77.

17. Vikas Pali, Nandan Mehta. Evaluation of Oil Content and Fatty Acid Compositions of Flax (Linum usitatissimum L.) Varieties of India, J Agr. Sci. 2014; 6(9):65-69.

18. Vipin Kumar Singh SA, Kerkhi, Shivendra Pratap Singh, Prakriti Tomar. Study on genetic variability, heritability and genetic advance for grain yield and yield component traits (Linum usitatissimum L.), J Pharmacognosy and Phytochemistry. 2019; 8(2):761-765.

19. Vishnuvardhan KM, Rao SS. Stability analysis for yield and its attributing characters in linseed (Linum usitatissimum L.), Intl. J Plant Animal and Environ. Sci. 2012; 4(2):408-411.

20. Walsh RJ. Linseed oil protection for New York State Thruway bridges, Civil Engg. 1965; 15(2):39-41. 